\title{
NUTRITION, DRY MATTER ACCUMULATION AND PARTITIONING AND PHOSPHORUS USE EFFICIENCY OF POTATO GROWN AT DIFFERENT PHOSPHORUS LEVELS IN NUTRIENT SOLUTION ${ }^{(1)}$
}

\author{
Adalton Mazetti Fernandes ${ }^{(2)} \&$ Rogério Peres Soratto ${ }^{(3)}$
}

\begin{abstract}
SUMMARY
High rates of phosphate fertilizers are applied to potato (Solanum tuberosum L.), which may cause antagonistic interactions with other nutrients and limit crop yields when over-supplied. The purpose of this study was to evaluate the influence of phosphorus (P) levels in nutrient solution on $\mathrm{P}$ use efficiency, nutritional status and dry matter (DM) accumulation and partitioning of potato plants cv. Ágata. The experiment was carried out in a greenhouse, arranged in a completely randomized block design with four replications. Treatments consisted of seven $P$ levels in nutrient solution $\left(0,2,4,8,16,31\right.$, and $\left.48 \mathrm{mg} \mathrm{L}^{-1}\right)$. Plants were harvested after 28 days of growth in nutrient solution, and separated in roots, stems and leaves for evaluations. The treatment effects were analyzed by regression analysis. Phosphorus levels of up to $8 \mathrm{mg} \mathrm{L}^{-1}$ increased the root and shoot DM accumulation, but drastically decreased the root/shoot ratio of potato cv. Ágata. Higher $\mathrm{P}$ availability increased $P$ concentration, accumulation and absorption efficiency, but decreased $\mathrm{P}$ use efficiency. Higher $\mathrm{P}$ levels increased the $\mathrm{N}, \mathrm{P}, \mathrm{Mg}, \mathrm{Fe}$, and Mn concentrations in roots considerably and decreased $K, S, C u$, and $\mathrm{Zn}$ concentrations. In shoot biomass, N, P, K, and Ca concentrations were significantly increased by $\mathrm{P}$ applied in solution, unlike $\mathrm{Mg}$ and $\mathrm{Cu}$ concentrations. Although higher $P$ levels $\left(>8 \mathrm{mg} \mathrm{L}^{-1}\right)$ in nutrient solution increased $P$ concentration, accumulation and absorption efficiency, the DM accumulation and partitioning of potato cv. Ágata were not affected.
\end{abstract}

Termos de indexação: Solanum tuberosum, dry matter, mineral nutrition, nutrient interaction.

\footnotetext{
(1) Received for publication in November 11, 2011 and approved in July 16, 2012.

(2) $\mathrm{PhD}$ student in Agronomy (Agriculture) from the College of Agricultural Sciences, São Paulo State University - FCA/UNESP, P.O. Box 37. CEP 18610-307 Botucatu (SP), Brazil. E-mail: adalton@fca.unesp.br

(3) Associate Professor at Department of Crop Science, FCA/UNESP, Botucatu (SP), Brazil. Research award from CNPq. E-mail: soratto@fca.unesp.br
} 


\title{
RESUMO: NUTRIÇÃO, ACÚMULO E PARTIÇÃO DA MATÉRIA SECA E EFICIÊNCIA DE UTILIZAÇÃO DO FÓSFORO PELA BATATEIRA SOB DOSES DE FÓSFORO EM SOLUÇÃO NUTRITIVA
}

\begin{abstract}
No cultivo da batata (Solanum tuberosum L.) são utilizadas altas doses de fertilizantes fosfatados, os quais, se fornecidos em excesso, podem causar interações antagonistas com outros nutrientes e limitar a produtividade dessa cultura. Diante disso, objetivou-se com este trabalho avaliar a influência de doses de fósforo $(P)$ no acúmulo e partição de matéria seca (MS), na eficiência de utilização do P pela planta e na nutrição da batateira cv. Ágata, cultivada em solução nutritiva. $O$ experimento foi conduzido em casa de vegetação, no delineamento experimental em blocos ao acaso, com quatro repetições. Os tratamentos foram constituídos por sete doses de P na solução nutritiva (0, 2, 4, 8, 16, 31 e $\left.48 \mathrm{mg} \mathrm{L}^{-1}\right)$. Após 28 dias de cultivo nas soluções nutritivas, as plantas foram colhidas, separadas em sistema radicular, hastes e folhas e avaliadas. O efeito dos tratamentos foi analisado mediante análise de regressão. O aumento nas doses de P na solução nutritiva até $8 \mathrm{mg} \mathrm{L}^{-1}$ incrementou a produção de MS de raízes e da parte aérea, porém reduziu drasticamente a relação raiz/parte aérea da batateira cv. Ágata. A elevação da disponibilidade de P incrementou o teor, o acúmulo e a eficiência de absorção, mas diminuiu a eficiência de utilização desse nutriente pela planta. O aumento nas doses de $\mathrm{P}$ incrementou de forma expressiva os teores radiculares de $\mathrm{N}, \mathrm{P}, \mathrm{Mg}, \mathrm{Fe}$ e $\mathrm{Mn}$ e diminuiu os teores de $K, S$, Cu e Zn. Na parte aérea, os teores de N, P, Ke Ca apresentaram aumentos significativos em resposta às doses de P na solução, ao passo que os teores de $\mathrm{Mg}$ e Cu foram reduzidos. Apesar de doses elevadas de $P\left(>8 \mathrm{mg} \mathrm{L}^{-1}\right)$ na solução nutritiva aumentarem o teor, o acúmulo e a eficiência de absorção do nutriente, não interferem na produção e partição de MS da batateira cv. Ágata.
\end{abstract}

Termos de indexação: Solanum tuberosum, matéria seca, nutrição mineral, interação de nutrientes.

\section{INTRODUCTION}

Potato (Solanum tuberosum L.) is one of the main Brazilian crops due to its nutritional and economic importance. Agata is one of the most cultivated cultivars and accounts for about $55 \%$ of the entire potato production in Brazil (Abba, 2010).

Potato is highly responsive to soil-applied nutrients, especially to phosphorus $(\mathrm{P})$, due to its short cycle and high yield potential. Phosphorus is essential for plants, mainly for the metabolic processes related to energy uptake, and therefore limiting for potato development. Plant growth is delayed at low-P levels already in initial stages; besides, number and length of roots and stolon are reduced as well as tuber yield (Fontes, 1997). To maximize yields, $\mathrm{P}$ is a nutrient that should therefore be available in adequate quantities from the early growth stages (Hu et al., 2010).

The efficiency of potato plants to adsorb soil $\mathrm{P}$ is considered low (Dechassa et al., 2003), which has led to the application of high soluble phosphate amounts to the crop, to ensure soil $\mathrm{P}$ availability. However, the application of high $\mathrm{P}$ doses may cause environmental and economical problems as well as an nutritional imbalance in potato plants (Hopkins et al., 2008). Nevertheless, little attention has been paid to the potentially negative effects of excessive applications of $\mathrm{P}$ on the other nutrients and on plants grown in rotation with potato (Barben et al., 2010a).
Phosphorus concentrations in soil solution are very low and frequently vary from 0.002 to $2 \mathrm{mg} \mathrm{L}^{-1}$ in agricultural soils (Fardeau, 1996). However, $\mathrm{P}$ in soil solution is not the only source available to plants, because as absorption occurs, solution $\mathrm{P}$ is constantly replenished by dissolution of labile $\mathrm{P}$, which maintains the balance of $\mathrm{P}$ in soil solution (Raij, 2011). Studies have shown that the determination of $\mathrm{P}$ in solution, which varies according to the characteristics of each soil, is not a good single indicator of $\mathrm{P}$ availability to plants, (Beckwith, 1965; Smyth \& Sanchez, 1980; Novais et al., 2007). Still, further research on $\mathrm{P}$ in nutrient solution is important to understand the development pattern of the plant and evaluate the influence of $\mathrm{P}$ on the other nutrients, since the growth-stimulating $\mathrm{P}$ concentrations in nutrient solution are usually higher than the P levels in the soil solution.

Several studies have shown that the P nutritional status can affect the absorption of other nutrients and, consequently, influence crop nutrition and production. The plant requirement of magnesium $(\mathrm{Mg})$ can be related to the $\mathrm{P}$ levels in nutrient solution (Vichiato et al., 2009). Phosphorus also interacts positively with nitrogen $(\mathrm{N})$ uptake and plant growth (Fageria, 2001), and P deficiency reduces the uptake of both nitrate (Araújo \& Machado, 2006) and ammonium (Alves et al., 1996). The application of high $\mathrm{P}$ levels increases the severity of zinc ( $\mathrm{Zn})$ deficiency in soils with low Zn levels (Fageria, 2001). 
The interaction between $\mathrm{P}$ and iron ( $\mathrm{Fe}$ ) may cause Fe deficiency symptoms, once Fe is internally immobilized, probably due to the formation of iron phosphate (Ayed, 1970). A balanced P nutrition is therefore essential for an appropriate development of potato.

Plants growing at low $\mathrm{P}$ levels develop adaptive mechanisms, such as changes in morphology and architecture of the root system (Raghothama \& Karthikeyan, 2005), as well as in physiological characteristics of roots (José et al., 2003). Root systems with larger root surface, length and density usually ensure a high $\mathrm{P}$ uptake efficiency when $\mathrm{P}$ availability is low (Hu et al., 2010). Under these low $\mathrm{P}$ conditions, the uptake efficiency by plants may also be improved by a higher root/shoot ratio (Machado \& Furlani, 2004; Schenk, 2006). Uptake efficiency of $\mathrm{P}$ may even be related to a higher uptake rate per unit of root length or mass (Dechassa et al., 2003). Plants develop physiological mechanisms to increase the $\mathrm{P}$ use efficiency, such as changes in $\mathrm{P}$ uptake kinetics and in the plant capacity to maintain normal metabolic levels when $\mathrm{P}$ tissue concentrations are low, ensuring a satisfactory dry matter (DM) or grain production (Machado \& Furlani, 2004). Understanding the dynamics in DM production and partitioning of potato $\mathrm{cv}$. Ágata grown at different $\mathrm{P}$ levels will therefore broaden the knowledge on plant physiology and on the possible interactions of $\mathrm{P}$ with the other nutrients, generating useful information for the improvement of potato management systems.

The purpose of this study was to evaluate the influence of $\mathrm{P}$ levels on DM accumulation and partitioning, $\mathrm{P}$ use efficiency and nutrition of potato plants, cv. Ágata, grown in nutrient solution.

\section{MATERIAL AND METHODS}

The experiment was conducted with potato plants, cv. Ágata, grown in nutrient solution in a greenhouse in Botucatu, São Paulo State, Brazil (22 $51^{\prime}$ S; $48^{\circ}$ 23 ' W; $765 \mathrm{~m}$ asl), between October and December 2010.

The experiment was arranged in a randomized complete block design, with seven $\mathrm{P}$ concentrations in nutrient solution (0, 2, 4, 8, 16, 31, and $\left.48 \mathrm{mg} \mathrm{L}^{-1}\right)$ and four replications.

Certified-type III seed tubers, cultivar Ágata, with $5-10-\mathrm{mm}$ sprouts, were soaked in solution with fungicides/bactericide $\left(3.75 \mathrm{~g} \mathrm{~L}^{-1}\right.$ Mancozeb, $2.5 \mathrm{~g} \mathrm{~L}^{-1}$ Pencycuron and $0.02 \mathrm{~g} \mathrm{~L}^{-1}$ Kasugamycin for $5 \mathrm{~min}$. Afterwards, the sprouts were distributed in 16 -L plastic boxes filled with washed sand to germinate.
Half-strength Hoagland solution (Hoagland \& Arnon, 1950) was applied three weeks later to standardize plant size. This application was repeated two days later. Four weeks after planting, the plantlets (stems) were pre-selected and transferred to and maintained in 4-L plastic pots filled with half-strength Hoagland solution (including P) for one week. Each experimental unit consisted of one pot with two plantlets.

From the second week on, full-strength Hoagland solution, modified according to the treatments in this experiment, were applied and replaced once a week. The solutions contained $\left(\mathrm{mg} \mathrm{L}^{-1}\right)$ : 210 of N (182 of $\mathrm{NO}_{3}{ }^{-}$and 28 of $\mathrm{NH}_{4}{ }^{+}$), 234 of $\mathrm{K}, 200$ of $\mathrm{Ca}, 48$ of $\mathrm{Mg}$, 64 of S, 0.5 of B, 0.02 of $\mathrm{Cu}, 5.0$ of EDTA-Fe, 0.5 of $\mathrm{Mn}, 0.01$ of Mo and 0.05 of $\mathrm{Zn}$. This nutrient solution consisted of a combination of the following sources: $\mathrm{KNO}_{3}, \mathrm{NH}_{4} \mathrm{NO}_{3}, \mathrm{KCl}, \mathrm{MgSO}_{4} .7 \mathrm{H}_{2} \mathrm{O}, \mathrm{Ca}\left(\mathrm{NO}_{3}\right)_{2} .4 \mathrm{H}_{2} \mathrm{O}$, $\mathrm{H}_{3} \mathrm{BO}_{3}, \mathrm{MnCl}_{2} \cdot 4 \mathrm{H}_{2} \mathrm{O}, \mathrm{ZnCl}_{2} \cdot 2 \mathrm{H}_{2} \mathrm{O}, \mathrm{CuSO}_{4} .5 \mathrm{H}_{2} \mathrm{O}$, $\left(\mathrm{NH}_{4}\right)_{6} \mathrm{MO}_{7} \mathrm{O}_{24} \cdot 4 \mathrm{H}_{2} \mathrm{O}$ and $\mathrm{FeCl}_{3}$. Phosphorus was added as $\mathrm{KH}_{2} \mathrm{PO}_{4}$ at concentrations of $0,2,4,8,16$, 31 , and $48 \mathrm{mg} \mathrm{L}^{-1}$.

During plant growth, deionized water was frequently added to all pots, readjusting the initial volume (maximum variation of $5 \%$ ). Solution aeration was constant and $\mathrm{pH}$ maintained at $5.5 \pm 0.5$, by daily correction with $\mathrm{HCl}$ or $\mathrm{NaOH}$. Cymoxanil + Mancozeb $(4+32 \mathrm{mg}$ of the active ingredient per plant) were applied twice to control late blight (Phytophthora infestans).

Four weeks after transplanting to nutrient solution, potato plants were harvested and separated into roots, stems and leaves. Stolons and tubers in initial development stages were considered stems. Samples were washed and dried to constant weight in a forced convection oven at $65{ }^{\circ} \mathrm{C}$. Shoot DM was obtained by the sum of leaves and stems; total DM was calculated by the sum of all parts. The root/shoot ratio was calculated from these data.

The plant material (roots, stems and leaves) of each pot separately, was ground in a Wiley Mill to pass through a 1-mm mesh screen. Samples were analyzed for nutrient concentrations according to Malavolta et al. (1997). Phosphorus accumulated in shoot and roots were estimated by multiplying nutrient concentrations in tissues and the amount of DM accumulated. From the amount of DM and P in plants, the following indexes were calculated: (a) P use efficiency = total $\mathrm{DM}$ / total amount of $\mathrm{P}$ in plants (Fageria et al., 1997); (b) uptake efficiency = total amount of $\mathrm{P}$ in plants / root DM (Swiader et al., 1994); (c) translocation efficiency $=($ amount of $\mathrm{P}$ in shoot $/$ total amount of $\mathrm{P}$ in plants) x 100 (Li et al., 1991).

The data were subjected to analysis of variance by the $\mathrm{F}$ test $(\mathrm{p}<0.05)$. Effects of $\mathrm{P}$ levels nutrient solution were evaluated by regression analysis through SigmaPlot 10.0 software (Systat, 2012). Polynomial and exponential models with best fitting were selected for each variable. Standard error of means was 
calculated based on dividing standard deviation by the square root of the sample size.

\section{RESULTS AND DISCUSSION}

Phosphorus deficiency symptoms were observed in treatments without this nutrient 15 days after transferring plants to nutrient solution, i.e. the plants had reduced growth, small leaves and thin stems. The survival of plants with no available $\mathrm{P}$ was attributed to the previous contact with full nutrient solution when grown in boxes with sand, which allowed an accumulation of sufficient $\mathrm{P}$ for the development in this period. Lange et al. (2005) studied the effects of micronutrient deficiency on castor bean and observed no visual symptoms of $\mathrm{Cu}, \mathrm{Mo}$ and $\mathrm{Zn}$ deficiency in treatments with nutrient omission; these authors explained that the plants had been grown in full nutrient solution for 23 days before treatment application, which ensured a sufficient accumulation of these nutrients for plant growth, as similarly observed for $\mathrm{P}$ in this study.

Root DM was influenced by $\mathrm{P}$ levels in solution $(p<0.05)$, but any equations could be fit to properly describe the results (Figure 1a). The effects of P levels of 2,4 and $8 \mathrm{mg} \mathrm{L}^{-1}$ did not differ from each other but improved root DM by $109 \%$, compared to the control; P levels of 16,31 and $48 \mathrm{mg} \mathrm{L}^{-1}$ increased root DM by only $63 \%$, compared to the control. Great variations in root morphology were observed at low $\mathrm{P}$ levels, since $\mathrm{P}$ deficiency led to the formation of thinner and longer roots to increase uptake efficiency (Barber, 1995). Therefore, the greatest root DM observed at lower P levels in solution was probably due to the presence of a larger number of thin long roots.

Increasing $\mathrm{P}$ levels in solution improved DM of stems, leaves, shoots and whole plant up to $8 \mathrm{mg} \mathrm{L}^{-1}$ (Figure 1b,c,d,e). Phosphorus levels above $8 \mathrm{mg} \mathrm{L}^{-1}$ did not influence plant growth, once the DM of stems, leaves, shoots, and whole plant were stabilized at 9.1, 12.5, 21.0 and $24.5 \mathrm{~g} /$ plant, respectively. Barben et al. (2010a) studied the effects of increasing P levels $\left(1,2,4,8,16,32\right.$, and $\left.63 \mathrm{mg} \mathrm{L}^{-1}\right)$ on the growth of potato cv. Russet Burbank in nutrient solution and found similar results. These authors reported $\mathrm{P}$ deficiency symptoms at $1.0 \mathrm{mg} \mathrm{L}^{-1}$ and toxicity symptoms at 32 and $63 \mathrm{mg} \mathrm{L}^{-1}$; vigorous growth was observed to the application of 4 and $8 \mathrm{mg} \mathrm{L}^{-1}$. In maize, Machado et al. (2001) observed that increasing P concentrations in nutrient solution improved shoot DM up to $8 \mathrm{mg} \mathrm{L}^{-1}$, but without effects on roots. It was expected that $P$ levels that obtain maximum DM yields exceed the $\mathrm{P}$ concentration (0.002 to $2 \mathrm{mg} \mathrm{L}^{-1}$ ) usually found in soil solution (Fardeau, 1996). This result is coherent since the labile $\mathrm{P}$ in soil exerts a buffer effect on the soil solution, constantly replacing
$\mathrm{P}$ to solution as the concentration is reduced (Raij, 2011).

Root/shoot ratio was higher at lower P levels, with a subsequent decrease as $\mathrm{P}$ in solution was increased (Figure 1f). From around $8 \mathrm{mg} \mathrm{L}^{-1}$, the root/shoot ratio was nearly stable up to the highest $\mathrm{P}$ level. The hagler root/shoot ratio observed at low than at higher $\mathrm{P}$ levels corroborated a number of studies (Balemi \& Schenk, 2009; Machado et al., 2001; Hu et al. 2010) and is related to a severe decrease in shoot DM compared to root DM (Figure 1a,d). According to Cakmak et al. (1994), the drastically reduced leaf development at low $\mathrm{P}$ levels results in a lower leaf demand for photoassimilates, leading to a higher translocation thereof to roots growth.

Phosphorus concentration and accumulation in roots increased up to highest $P$ level applied in nutrient solution were increased; conversely, $\mathrm{P}$ in shoot was increased up to the estimate level of $36 \mathrm{mg} \mathrm{L}^{-1}$ (Figure $2 \mathrm{a}, \mathrm{b})$. Levels of $\mathrm{P}$ above $36 \mathrm{mg} \mathrm{L}^{-1}$ resulted in lower concentrations and accumulated quantities of $\mathrm{P}$ in the shoot biomass, showing that very high $\mathrm{P}$ levels in solution do not lead to increased $\mathrm{P}$ uptake and DM yield (Figures 1e, 2a,b ). Barben et al. (2010a) also reported increases in $\mathrm{P}$ concentration in all parts of potato plant and that he maximum concentration was obtained at $32 \mathrm{mg} \mathrm{L}^{-1}$ of $\mathrm{P}$.

Phosphorus uptake rate per unit of root DM was higher with increasing $\mathrm{P}$ concentrations up to the maximum estimated level of $37 \mathrm{mg} \mathrm{L}^{-1}$ (Figure 2c). Uptake efficiency was not increased indefinitely at higher $\mathrm{P}$ concentrations, possibly because $\mathrm{P}$ uptake by plants occurs by ionic transporters, which have a limited number of absorption sites (Glass, 1990).

Phosphorus translocation efficiency to plant shoots was 66,77 and $86 \%$ in the treatments control, 2 and $4 \mathrm{mg} \mathrm{L}^{-1}$, respectively; at the other levels, percentages were around $90 \%$ (Figure 2d). As lower levels drastically reduced shoot DM (Figure 1d), more P was allocated in roots to ensure growth (Figure 1a). Machado et al. (2001) also found that maize plants proportionally allocated more $\mathrm{P}$ in roots, at the expense of shoots, at the lowest level in solution. According to Marschner (1995), P retention in roots is improved at insufficient levels, leading to redistribution via phloem and the supply of additional $\mathrm{P}$.

Increasing $\mathrm{P}$ levels in nutrient solution reduced $\mathrm{P}$ use efficiency (Figure 2e), once plant DM was stable at levels above $8 \mathrm{mg} \mathrm{L}^{-1}$ (Figure $1 \mathrm{e}$ ), whereas $\mathrm{P}$ concentrations in plants were still rising (Figure 2a), wich is in accord with Balemi \& Schenk (2009). Although higher $\mathrm{P}$ levels $\left(>8 \mathrm{mg} \mathrm{L}^{-1}\right)$ in the nutrient solution increase $\mathrm{P}$ tissue concentration, accumulation and plant uptake efficiency, the DM accumulation and partitioning of potato cv. Ágata was not affected, indicating that increasing $\mathrm{P}$ levels in soil at appropriate $\mathrm{P}$ availability do not influence yield. 

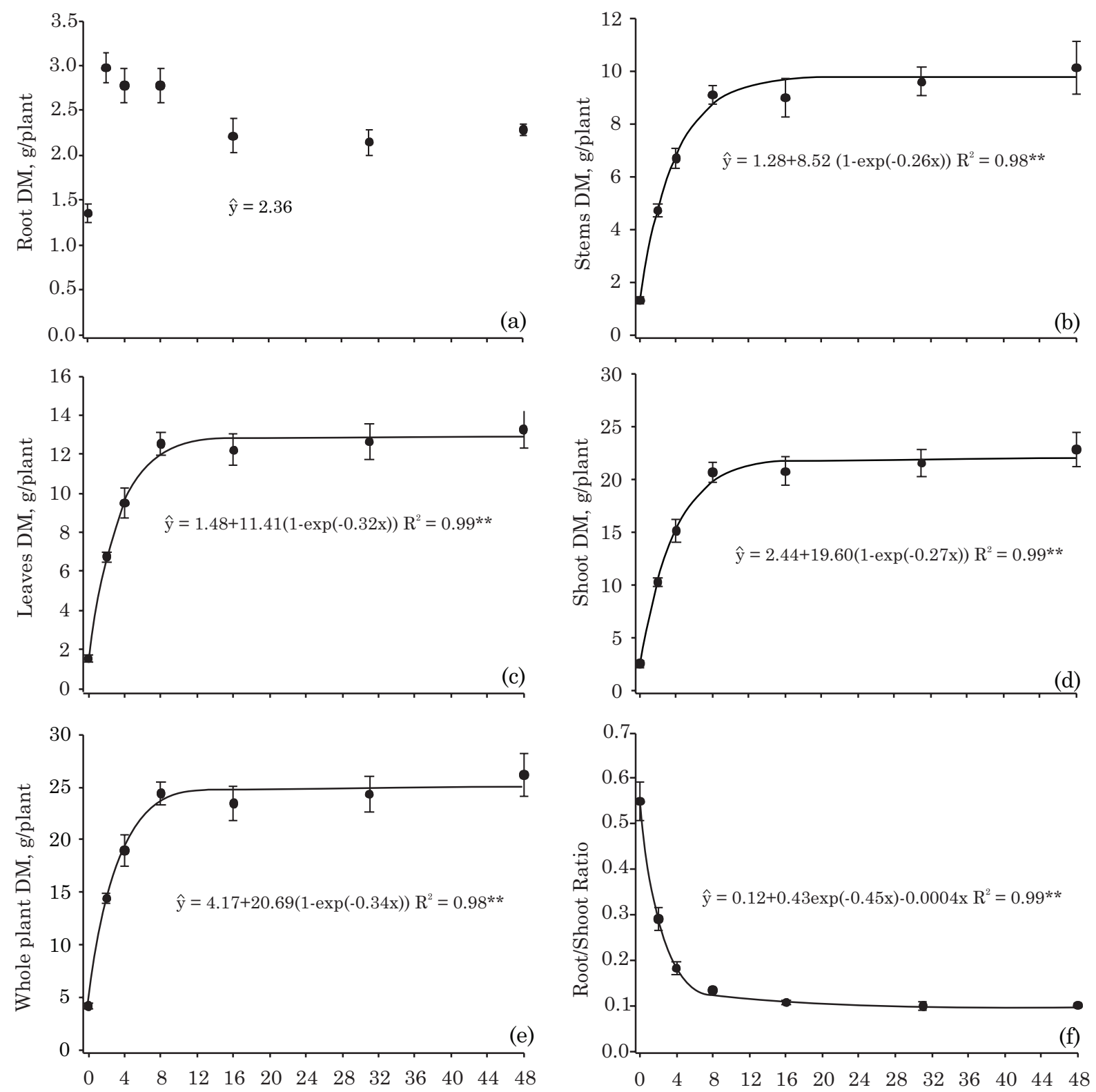

P level, $\mathrm{mg} \mathrm{L}^{-1}$

Figure 1. Dry matter (DM) accumulation in roots (a), stems (b), leaves (c), shoot (d), and whole plant (e) and root/shoot ratio (f) in potato plants, cv. Ágata, as affected by P levels in the nutrient solution. * p $>0.05$ and ** $p>0.01$. Vertical bars represent the standard error.

Analyzing plant nutrition, the $\mathrm{N}$ concentrations in roots and shoots were increased by $\mathrm{P}$ in solution up to estimated levels of 27 and $29 \mathrm{mg} \mathrm{L}^{-1}$, respectively (Figure 3a). Lower $\mathrm{N}$ concentrations resulting from lower P levels showed that nitrate (Araújo \& Machado, 2006) and ammonium (Alves et al., 1996) uptake is reduced at limited $\mathrm{P}$ levels. Alves et al. (1996) observed that $\mathrm{P}$ deficiency decreased total $\mathrm{N}$ concentrations in leaves as well as $\mathrm{N}$ and nitrate concentration in stems and roots of hybrid maize, indicating that low $\mathrm{P}$ levels reduced $\mathrm{N}$ uptake.
Potassium (K) concentration in roots decreased with increasing $\mathrm{P}$ in solution up to an estimated level of $27 \mathrm{mg} \mathrm{L}^{-1}$; in shoot, higher $\mathrm{P}$ levels increased $\mathrm{K}$ concentrations up to $26 \mathrm{mg} \mathrm{L}^{-1}$ (Figure $3 \mathrm{~b}$ ), suggesting that $\mathrm{P}$ influenced $\mathrm{K}$ translocation. Studies on enriched $\mathrm{P}\left({ }^{32} \mathrm{P}\right)$ have demonstrated that triphosphate adenosine (ATP) and triphosphate uridine (UTP), which are essential in metabolic processes, are rapidly formed as soon as P is absorbed by roots (Malavolta, 2004). Since the energy provided by ATP drives K towards the shoot, in other words, allows its entry into the 

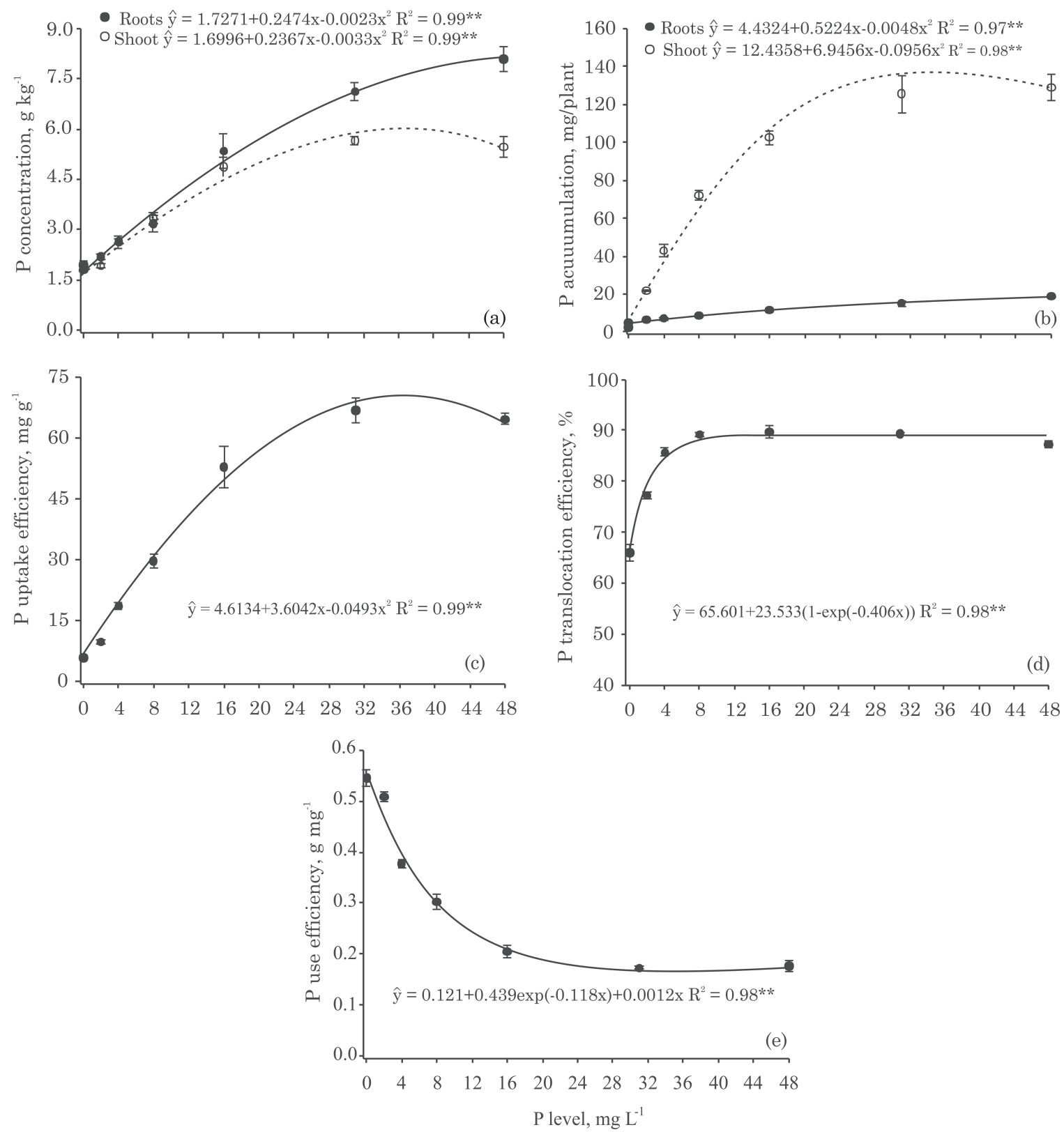

Figure 2. Phosphorus concentration (a) and accumulation (b) in roots and shoot, uptake efficiency (c), translocation efficiency (d) and use efficiency (e) in potato plants, cv. Ágata, as affected by $P$ levels in the nutrient solution. $* p>0.05$ and $* * p>0.01$. Vertical bars represent the standard error.

xylem through a $\mathrm{K}^{+}-\mathrm{H}^{+}$antiport system (Malavolta, 2005), the increased availability of $P$ probably led to a greater translocation of $\mathrm{K}$ to plant shoots.

Phosphorus levels in solution did not influence calcium $(\mathrm{Ca})$ concentrations in roots, which represented an average of $6.8 \mathrm{~g} \mathrm{~kg}^{-1}$ (Figure 3c). In shoot biomass, Ca concentrations were slightly increased up to an estimated level of $31 \mathrm{mg} \mathrm{L}^{-1}$, i.e. the standard solution of Hoagland \& Arnon (1950).

In the absence of $\mathrm{P}$, magnesium ( $\mathrm{Mg}$ ) concentrations in root and shoot biomass were similar.
Nevertheless, $\mathrm{P}$ levels in solution of up to $16 \mathrm{mg} \mathrm{L}^{-1}$ increased $\mathrm{Mg}$ in roots (Figure $3 \mathrm{~d}$ ), becoming stable at higher levels. In shoot biomass, Mg concentrations were reduced by $\mathrm{P}$ levels up to $2 \mathrm{mg} \mathrm{L}^{-1}$, and remained stable at the other levels. The increase in $\mathrm{Mg}$ concentrations in root may be related to the $\mathrm{Mg}$ requirement for the energy-transfer reactions into cells (Marschner, 1995), since Mg is a kinase enzyme activator and activates most reactions involving phosphate transfer (Fageria, 2001).

Increasing $\mathrm{P}$ levels of up to $32 \mathrm{mg} \mathrm{L}^{-1}$ in solution effectively reduced sulphur (S) concentrations. 

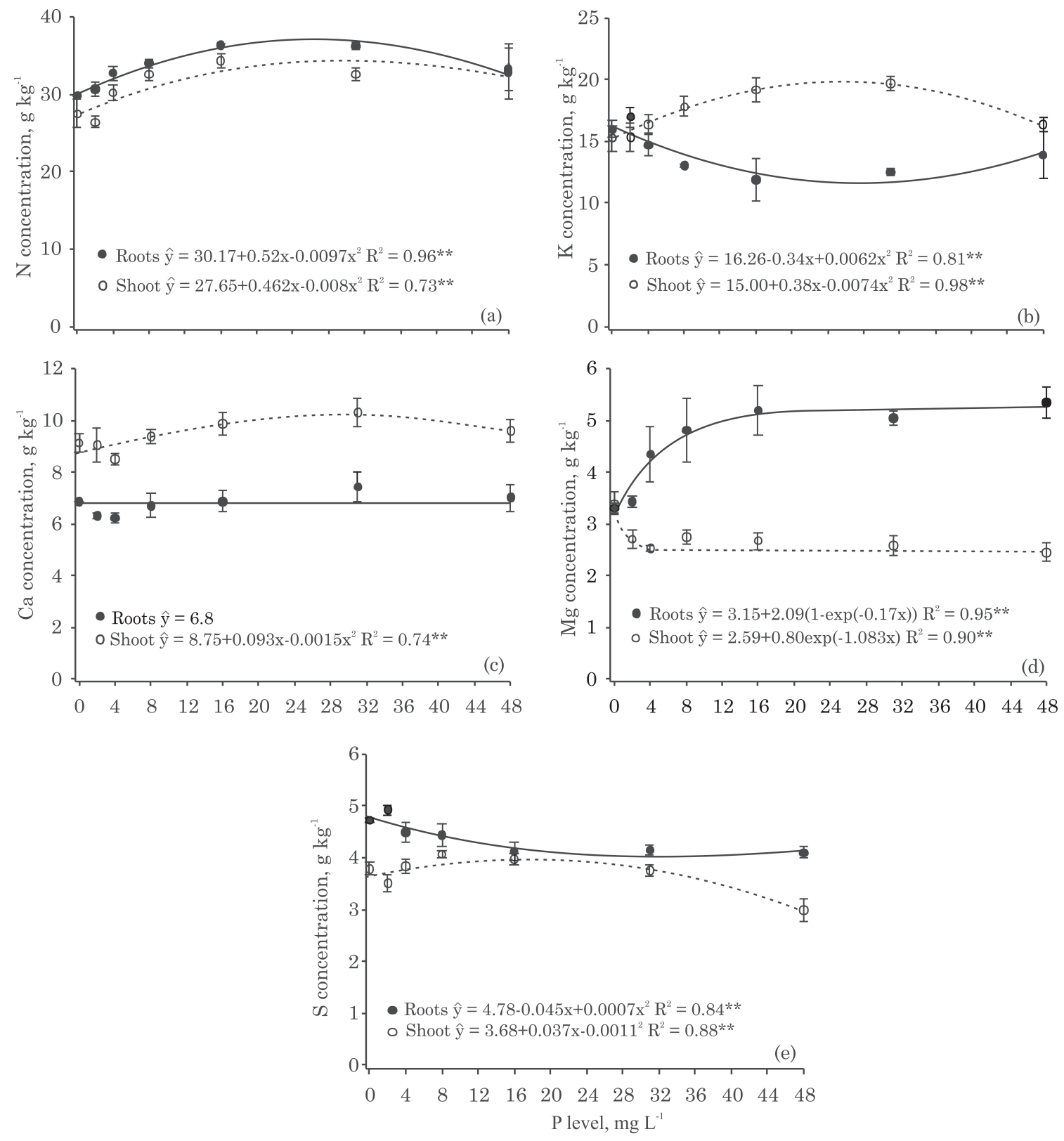

Figure 3. Nitrogen (a), potassium (b), calcium (c), magnesium (d), and sulphur (e) concentrations in roots and shoots biomass of potato plants, cv. Ágata, as affected by P levels in the nutrient solution. * p $>0.05$ and $* * p>0.01$. Vertical bars represent the standard error.

Sulphur concentrations in shoot biomass increased up to $17 \mathrm{mg} \mathrm{L}^{-1} \mathrm{P}$, to decrease at higher levels (Figure 3e), possibly due to dilution effects caused by increased shoot DM (Figure 1d). However, Aulakh \& Pasricha (1977) observed $\mathrm{S}$ accumulation in common bean plants (Phaseolus aureus L.), which decreased at $\mathrm{P}$ higher levels. According to these authors, sulphate and phosphate anions probably compete for the same sorption sites in roots or even for the same uptake pathways within roots and stems. In soil, phosphate fertilization reduces the amount of sulphate adsorbed in solid phase, therefore increasing availability in soil solution (Adams, 1980).
Boron (B) concentrations in roots and shoots biomass were not affected by the treatments (Figure 4a). Conversely, a linear decrease of copper $(\mathrm{Cu})$ concentrations in roots was found with increasing $\mathrm{P}$ levels in solution; $\mathrm{Cu}$ concentrations in shoot biomass were reduced up to an estimated dose of $42 \mathrm{mg} \mathrm{L}^{-1}$ of $\mathrm{P}$ (Figure 4b). Copper concentrations reduced by $\mathrm{P}$ seem to be related to changes in $\mathrm{Cu}$ availability in solution. Islam et al. (2009) reported that high P levels may lead to the formation of $\mathrm{Cu}$ phosphate, which is not available to plants. Studies about citrus species revealed lower leaf concentrations and uptake of $\mathrm{Cu}$, causing deficiency symptoms and decreasing growth 

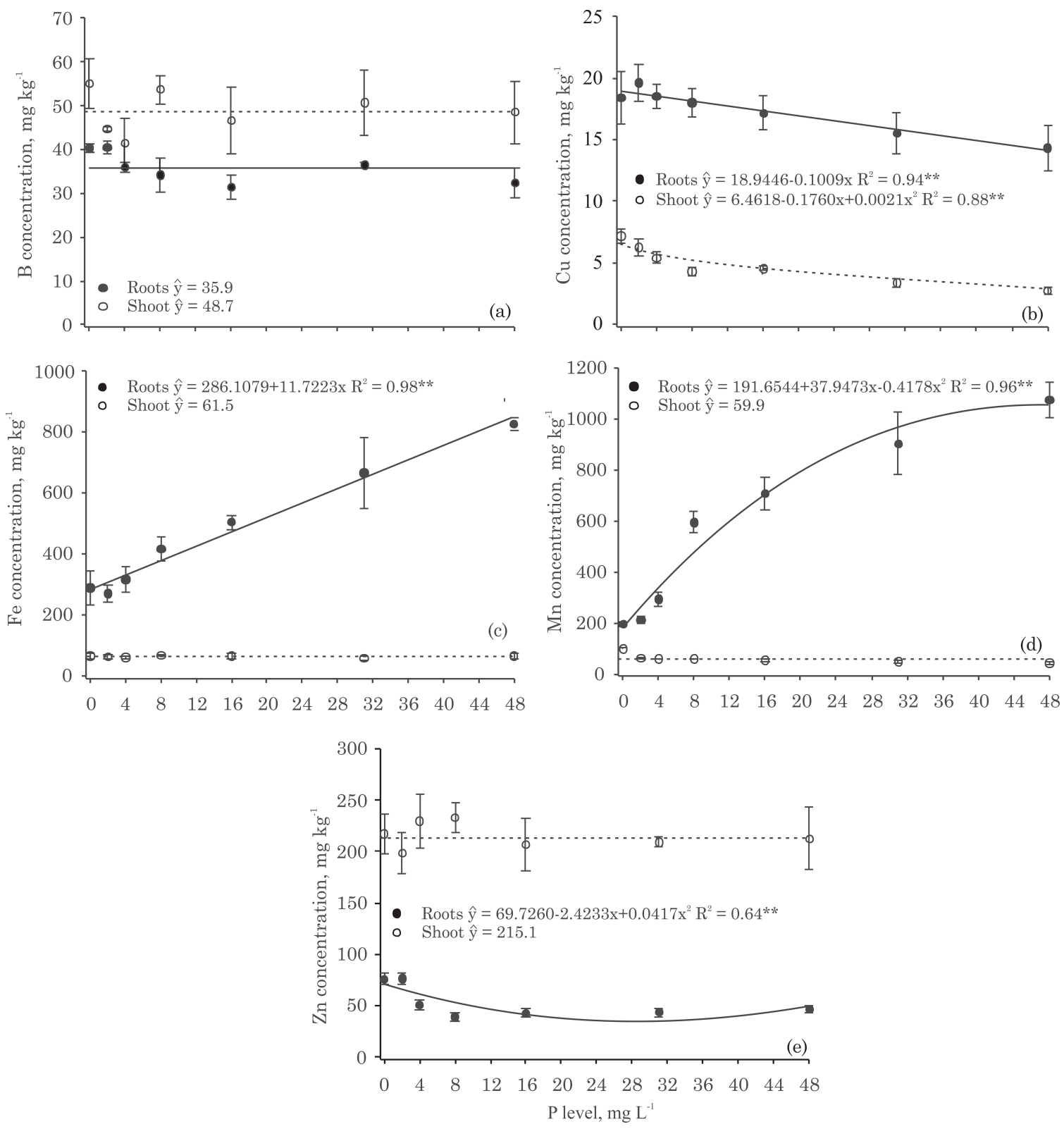

Figure 4. Boron (a), copper (b), iron (c), manganese (d), and zinc (e) concentrations in roots and shoots biomass of potato plants, cv. Ágata, as affected by $P$ levels in the nutrient solution. * $p>0.05$ and $* * p>$ 0.01. Vertical bars represent the standard error.

as $\mathrm{P}$ availability increased (Adams, 1980). Barben et al. (2010a) also reported effects of $\mathrm{P}$ levels on $\mathrm{Cu}$ concentrations in roots and shoots of potato plants (cv. Russet Burbank).

In roots, Fe concentrations were linearly increased by $\mathrm{P}$ levels. This could be explained by the internal Fe mobility in roots and transport inhibition of $\mathrm{Fe}$ from roots to shoots, as a consequence of iron phosphates being formed in roots (Fageria, 2001), once the $\mathrm{P}$ concentrations in roots also increased at higher $\mathrm{P}$ availability in solution and Fe concentrations in shoot biomass were stable (Figures $2 \mathrm{a}$ and $4 \mathrm{c}$ ). Similarly, Barben et al. (2010a) observed higher Fe concentrations in roots, but no effects on potato shoots, at increasing $\mathrm{P}$ levels in nutrient solution.

Manganese $(\mathrm{Mn})$ concentrations in roots were increased by $\mathrm{P}$ levels in solution up to $45 \mathrm{mg} \mathrm{L}^{-1}$, demonstrating that $\mathrm{P}$ influenced $\mathrm{Mn}$ accumulation (Figure 4d). Barben et al. (2010a) observed that increasing $\mathrm{P}$ in nutrient solution drastically increased Mn concentrations only in roots. The authors inferred a possible formation of P-Mn complexes in root tissues. Follow-up studies showed that increasing $\mathrm{P}$ concentrations improved $\mathrm{Mn}$ accumulation in potato roots and shoots, but only at appropriate $\mathrm{Mn}$ levels in solution, suggesting that $\mathrm{P}$ 
probably influenced Mn uptake and transport (Barben et al., 2010c).

Unlike Fe and Mn, zinc ( $\mathrm{Zn}$ ) root concentrations were reduced at higher $\mathrm{P}$ levels (Figure 4e). According to Malavolta et al. (1997), there could be insolubilization of $\mathrm{Zn}$ by phosphate at the root surface when $\mathrm{P}$ is oversupplied, decreasing uptake and inhibiting $\mathrm{Zn}$ uptake by $\mathrm{P}$ non-competitively. An antagonism between $\mathrm{P}$ and $\mathrm{Zn}$ can also occur, particularly when the concentration of one of the elements exceeds the critical level (Araújo \& Machado, 2006). Barben et al. (2010b) observed that an excessive $\mathrm{P}$ accumulation may reduce $\mathrm{Zn}$ activity as a consequence of interaction with micronutrients such as $\mathrm{Mn}$, although high $\mathrm{P}$ levels in solution do not directly decrease $\mathrm{Zn}$ concentrations in the potato cultivar Russet Burbank, or even induce Zn deficiency in plants.

Iron, $\mathrm{Mn}$ and $\mathrm{Zn}$ concentrations in potato shoot biomass were not affected by $\mathrm{P}$ levels in solution (Figure 4c,d,e). Barben et al. (2010b) also found that increasing $\mathrm{P}$ levels in nutrient solution did not reduce Zn concentration in shoots of potato cultivar Russet Burbank, grown at appropriate $\mathrm{Zn}$ levels. However, $\mathrm{Zn}$ concentration in shoot biomass was on average $215 \mathrm{mg} \mathrm{kg}^{-1}$, i.e. much higher than in the roots. High Zn concentrations in shoot biomass may be a result of Cymoxanil/Mancozeb applications during the experiment, which may have influenced $\mathrm{P}$ effects on $\mathrm{Zn}$ concentrations; these fungicides contain considerable Zn concentrations. Results show that although high $\mathrm{P}$ fertilizer levels are applied to potato, Zn-based fungicides may minimize deficiency symptoms. According to Fontes et al. (1999), Zn-based fungicides increase Zn leaf concentrations and tuber yield.

\section{CONCLUSIONS}

1. Phosphorus levels in the nutrient solution up to $8 \mathrm{mg} \mathrm{L}^{-1}$ increased root and shoot DM accumulation of potato cultivar Ágata, but reduced the root/shoot ratio drastically.

2. Better $P$ availability in nutrient solution increased $\mathrm{P}$ concentrations, accumulation and uptake efficiency, but reduced use efficiency of the nutrient in potato cv. Ágata.

3. Higher P levels increased N, P, Mg, Fe and Mn concentrations in potato roots considerably, but decreased $\mathrm{K}, \mathrm{S}, \mathrm{Cu}$ and $\mathrm{Zn}$ concentrations. In shoot biomass, N, P, K and Ca concentrations were significantly increased by $\mathrm{P}$ levels in solution, in contrast to $\mathrm{Mg}$ and $\mathrm{Cu}$ concentrations.

4. Although $\mathrm{P}$ levels above $8 \mathrm{mg} \mathrm{L}^{-1}$ in solution increased the $\mathrm{P}$ concentrations, accumulation and uptake efficiency in potato cv. Ágata, they did not influence DM accumulation and partitioning.

\section{ACKNOWLEDGEMENTS}

The authors are indebted to the State of São Paulo Research Foundation (FAPESP) for financial support and a scholarship of the first author, and to the National Council for Scientific and Technological Development $(\mathrm{CNPq})$ for Research award of the second author.

\section{LITERATURE CITED}

ASSOCIAÇÃO BRASILEIRA DA BATATA - ABBA. Variedades. R. Batata Show, 10:1-4, 2010.

ADAMS, F. Interactions of phosphorus with other elements in soils and in plants. In: KHASAWNEH, F.E.; SAMPLE, B.C. \& KAMPRATH, E.J., eds. The role of phosphorus in agriculture. Madison, American Society of Agronomy, 1980. p.655-680

ALVES, V.M.C.; NOVAIS, R.F.; OLIVEIRA, M.F.G. \& BARROS, N.F. Efeito da omissão de fósforo na absorção de nitrogênio por híbridos de milho (Zea mays L.). R. Ceres, 43:435-443, 1996 .

ARAÚJO, A.P. \& MACHADO, C.T.T. Fósforo. In: FERNANDES, M.S., ed. Nutrição mineral de plantas. Viçosa, MG, Sociedade Brasileira de Ciência do Solo, 2006. p.253-280.

AULAKH, M.S. \& PASRICHA, N.S. Interaction effect of sulphur and phosphorus on growth and nutrient content of moong (Phaseolus aureus L.). Plant Soil, 47:341-350, 1977.

AYED, I.A. A study of the mobilization of iron in tomato roots by chelate treatments. Plant Soil, 32:18-26, 1970.

BALEMI, T. \& SCHENK, M.K. Genotypic variation of potato for phosphorus efficiency and quantification of phosphorus uptake with respect to root characteristics. J. Plant Nutr. Soil Sci., 172:669-677, 2009.

BARBEN, S.A.; HOPKINS, B.G.; JOLLEY, V.D.; WEBB, B.L \& NICHOLS, B.A. Optimizing phosphorus and zinc concentrations in hydroponic chelator-buffered nutrient solution for Russet Burbank potato. J. Plant Nutr., 33:557570, 2010a.

BARBEN, S.A.; HOPKINS, B.G.; JOLLEY, V.D.; WEBB, B.L \& NICHOLS, B.A. Phosphorus and zinc interactions in chelator-buffered solution grown Russet Burbank potato. J. Plant Nutr., 33:587-601, 2010b.

BARBEN, S.A.; HOPKINS, B.G.; JOLLEY, V.D.; WEBB, B.L. \& NICHOLS, B.A. Phosphorus and manganese interactions and their relationships with zinc in chelatorbuffered solution grown Russet Burbank potato. J. Plant Nutr., 33:752-769, 2010c.

BARBER, S.A. Soil nutrient bioavailability: a mechanistic approach. 2.ed. New York, John Wiley \& Sons, 1995. $414 \mathrm{p}$. 
BECKWITH, R.S. Sorbed phosphate at standart supernatant concentration as an estimate of the phosphate needs of soils. Austr. J. Exper. Agric. Anim. Husb., 5:52-58, 1965.

CAKMAK, I.; HENGELER, C. \& MARSCHNER, H. Partitioning of shoot and root dry matter and carbohydrates in bean plants suffering from phosphorus, potassium and magnesium deficiency. J. Exper. Bot., 45:1245-1250, 1994.

DECHASSA, N.; SCHENK, M.K.; CLAASSEN, N. \& STEINGROBE, B. Phosphorus efficiency of cabbage (Brassica oleraceae L. var. capitata), carrot (Daucus carota L.), and potato (Solanum tuberosum L.). Plant Soil, 250:215-224, 2003.

FAGERIA, N.K.; BALIGAR, V.C. \& ALLAN JONES, C. Growth and mineral nutrition of field crops. 2.ed. New York, Marcel Dekker, 1997. 624p.

FAGERIA, V.D. Nutrient interactions in crop plants. J. Plant Nutr., 24:1269-1290, 2001.

FARDEAU, J.C. Dynamics of phosphate in soils. An isotopic outlook. Fert. Res., 45:91-100, 1996.

FONTES, P.C.R. Preparo do solo, nutrição mineral e adubação da batateira. Viçosa, MG, Universidade Federal de Viçosa, 1997. 42 p.

FONTES, P.C.R.; MOREIRA, M.A.; FONTES, P.C.R. \& CARDOSO, A.A. Effects of zinc fungicides and different zinc fertilizer application methods on soluble and total zinc in potato plant shoots. Comm. Soil Sci. Plant Anal., 30:1847-1859, 1999.

GLASS, A.D.M. Ion absorption and utilization: the cellular level. In: BALIGAR, V.C. \& DUNCAN, R.R., eds. Crops as enhancers of nutrient use. San Diego, Academic Press, 1990. p.41-64.

HOAGLAND, D.R. \& ARNON, D.L. The water culture methods for growing plants without soil. Berkeley, California Agriculture Experiment Station, 1950. 32p. (Bulletin, 347)

HOPKINS, B.G.; ROSEN, C.J.; SHIFFLER, A.K. \& TAYSOM, T.W. Enhanced efficiency fertilizers for improved nutrient management: potato (Solanum tuberosum). Crop Management Online doi:10.1094/CM-2008-0317-01-RV. 2008. Disponível em: http://www.plantmanagementnetwork.org/ $\mathrm{pub} / \mathrm{cm} / \mathrm{sym}$ posium/enhanced/potato/

HU, Y.; YE, X.; SHI, L.; DUAN, H. \& XU, F. Genotypic differences in root morphology and phosphorus uptake kinetics in Brassica napus under low phosphorus supply. J. Plant Nutr., 33:889-901, 2010.

ISLAM, M.; ALI, S. \& HAYAT, R. Effect of integrated application of phosphorus and sulphur on yield and microutrient uptake by chickpea (Cicer arietinum L.). Intern. J. Agric. Biol., 11:33-38, 2009

JOSÉ, L.; ALFREDO, C. \& LUIS, H. The role of nutrient availability in regulating root architecture. Curr. Opin. Plant Biol., 6:280-287, 2003.
LANGE, A.; MARTINES, A.M.; SILVA, M.A.C.; SORREANO, M.C.M.; CABRAL, C.P. \& MALAVOLTA, E. Efeito de deficiência de micronutrientes no estado nutricional da mamoneira cultivar 'Iris'. Pesq. Agropec. Bras., 40:61-67, 2005 .

LI, B.; McKEAND, S.E. \& ALLEN, H.L. Genetic variation in nitrogen use efficiency of loblolly pine seedlings. For. Sci., 37:613-626, 1991.

MACHADO, C.T. \& FURLANI, A.M.C. Kinetics of phosphorus uptake and root morphology of local and improved varieties of maize. Sci. Agric., 61:69-76, 2004.

MACHADO, C.T.T.; FURLANI, A.M.C. \& MACHADO, A.T. Índices de eficiência de variedades locais e melhoradas de milho ao fósforo. Bragantia, 60:225-238, 2001.

MALAVOLTA, E. O fósforo na planta e interações com outros elementos. In: YAMADA, T. \& ABDALLA, S.R.S., eds. Fósforo na agricultura brasileira. Piracicaba, Potafos, 2004. p.35-105.

MALAVOLTA, E. Potássio - absorção, transporte e redistribuição na planta. In: YAMADA, T. \& ROBERTS, T.L., eds. Potássio na agricultura brasileira. Piracicaba, Potafos, 2005. p.179-238

MALAVOLTA, E.; VITTI, G.C. \& OLIVEIRA, S.A. Avaliação do estado nutricional de plantas: Princípios e aplicações. Piracicaba, Potafos, 1997. 308p.

MARSCHNER, H. Mineral nutrition of higher plants. 2.ed. London, Academic Press, 1995. 889p.

NOVAIS, R.F.; SMYTH, T.J. \& NUNES, F.N. Fósforo. In NOVAIS, R.F.; ALVAREZ V., V.H.; BARROS, N.F .; FONTES, R.L.F.; CANTARUTTI, R.B. \& NEVES, J.C.L., eds. Fertilidade do solo. Viçosa, MG, Sociedade Brasileira de Ciência do Solo, 2007. p.471-550.

RAGHOTHAMA, K.G. \& KARTHIKEYAN, A.S. Phosphate acquisition. Plant Soil, 274:37-49, 2005.

RAIJ, B.van. Fertilidade do solo e manejo de nutrientes. Piracicaba, IPNI, 2011. 420p.

SCHENK, M.K. Nutrient efficiency of vegetable crops. Acta Hortic., 700:21-34, 2006.

SMYTH, T.J. \& SANCHEZ, P.A. Níveis críticos de fósforo para arroz de sequeiro em um Latossolo dos cerrados. R. Bras. Ci. Solo, 4:88-92, 1980.

SYSTAT SOFTWARE INC - SSI. A scientific data management company. Disponível em: http://www.sigmaplot.com/ index.php. Acesso em: junho 2012.

SWIADER, J.M.; CHYAN, Y. \& FREIJI, F.G. Genotypic differences in nitrate uptake and utilization efficiency in Pumpkin hybrids. J. Plant Nutr., 17:1687-1699, 1994.

VICHIATO, M.; CARVALHO, J.G.; VICHIATO, M.R.M. \& SILVA, C.R.R. Interações fósforo-magnésio em mudas de mamoeiros Tainung $\mathrm{n}^{\circ} .1$ e Improved Sunrise Solo 72/ 12. Ci Agrotec., 33:1265-1271, 2009. 